\begin{tabular}{|l|l|r|}
\hline A1 Fitrah & \\
Journal Of Early Childhood Islamic Education & Pengembangan Nilai-nilai Kultur Positif \\
ISSN $:$ 2599-2287 & Pendidikan Anak Usia Dini Berbasis Islam \\
Vol.1 No.2 Januari 2018 & Buyung Surahman \\
\hline
\end{tabular}

\title{
PENGEMBANGAN NIALI-NILAI KULTUR POSITIF PENDIDIKAN ANAK USIA DINI BERBASIS ISLAM
}

\begin{abstract}
Abstrak
Penelitian ini bertujuan untuk merumuskan pengembangan nilai-nilai kultur positif Pendidikan Anak Usia Dini. Pengembangan nilai-nilai kultur positif tersebut berupa nilai keimanan, semangat hidup, keterbukaan, kejujuran, spirit belajar, menyadari diri, tata krama, persatuan dan kesatuan, nilai sikap, disiplin, tanggung jawab, dan kebersamaan. Permasalahannya bagaimana Pendidikan Anak Usia Dini mengembangkan nilai-nilai kultur positif tersebut?. Penelitian ini merupakan penelitian kualitatif yang menggunakan pendekatan naturalistik. Data yang diteliti adalah data pengembangan nilai-nilai kultur positif pada tiga (3) Pendidikan Anak Usia Dini terakreditasi A di Bengkulu. Pengumpulan data dilakukan dengan teknik dokumentasi, observasi, dan wawancara. Data dianalisis menggunakan analisis domain, taksonomi, komponensial, dan analisis tema kultural yang mengacu pada buku Spradley. Temuan penelitian membuktikan bahwa bentuk dan cara Pendidikan Anak Usia Dini melakukan pengembangan niali-nilai kultur positif berupa: nilai keimanan, semangat hidup, keterbukaan, kejujuran, spirit belajar, menyadari diri, tata krama, persatuan dan kesatuan, nilai sikap, disiplin, tanggung jawab, dan kebersamaan. Pengembangan nilai-nilai ini dibungkus dan diterapkan oleh siswa dan guru di lingkungan sekolah, sehingga membuat sekolah bercirikan Islami ini maju dan berkembang dan dicintai oleh masyarakat.
\end{abstract}

Kata kunci: Pengembangan Nilai-nilai

\section{Pendahuluan}

Penanaman nilai-nilai kultur positif perlu dikembngkan di Pendidikan Anak Usia Dini (PAUD) seperti dikemukakan oleh Fadlillah (2013: 40-41), nilai-nilai kultur positif yang perlu dikembangkan diantaranya: nilai religius, jujur, toleransi, disiplin, mandiri, peduli sosial, dan tanggungjawab. Pendidikan Anak Usia Dini merupakan suatu tahap pendidikan yang tidak dapat diabaikan, karena ikut menentukan perkembangan dan 


\begin{tabular}{|c|c|c|}
\hline$\Leftrightarrow$ & $\begin{array}{l}\text { A1 Fitrah } \\
\text { Journal Of Early Childhood Islamic Education } \\
\text { ISSN : 2599-2287 } \\
\text { Vol.1 No.2 Januari } 2018\end{array}$ & $\begin{array}{r}\text { Pengembangan Nilai-nilai Kultur Positif } \\
\text { Pendidikan Anak Usia Dini Berbasis Islam } \\
\text { Buyung Surahman }\end{array}$ \\
\hline
\end{tabular}

keberhasilan anak yang akan datang. Oleh karenanya adanya PAUD diharapkan anak akan tumbuh dan berkembang dengan identitas diri yang kuat (Noorlaila, 2010: 8). Penanaman nilai-nilai positif pada Anak Usia Dini yang perlu dimuatkan pada proses pembelajaran PAUD seperti dikemukakan oleh Hamid Darmadi (2007: 56-57) yaitu: (1) mengajarkan kepada anak agar mau bersosialisasi dan mampu bekerjasama dengan teman-teman sepermainan; (2) mengajarkan kepada anak agar memiliki sikap tenggang rasa, menolong sesama yang sedang membutuhkan; (3) mengajarkan kepada anak utuk mau berbagi bersama teman serta memiliki rasa peduli kepada orang lain; (4) mengajarkan tata bicara yang sopan, baik, dan benar kepada anak-anak; memperkenalkan kepada anak tentang berbagai macam aturan baik yang ada di keluarga, lingkungan sekolah maupun di jalan; (6) melatih anak-anak untuk mentaati peraturan-peraturan tersebut; dan (7) mengajarkan kepada anak untuk belajar menerima konsekuensi atau akibat jika melanggar peraturan.

Upaya penanaman nilai-nilai positif pada Pendidikan Anak Usia Dini di Indonesia telah dilakukan oleh pemerintah dengan mengupayakan: (1) pemerataan layanan, peningkatan mutu, dan efesiensi penyelenggaraan pendidikan dini;

mengupayakan peningkatan kesadaran dan kemampuan masyarakat dalam memberikan pelayanan pendidikan dini; dan mempersiapkan anak sedini mungkin agar kelak memilki kesiapan memasuki pendidikan lebih lanjut (Sujiono, 2009: 49), dan impian pemerintah adalah terwujudnya anak usia dini yang cerdas, sehat, ceria, dan berakhlak mulia serta memiliki kesiapan fisik maupun mental dalam memasuki pendidikan lebih lanjut. Mengacu pada Sistem Pendidikan Nsional 2003, PAUD memegang peran yang sangat penting dalam mengembangkan dan menyiapkan pribadi peserta didik secara utuh dan menyeluruh. Menurut Peraturan Menteri Pendidikan Nasional Republik Indonesia Nomor 58 Tahun 2009 (dalam Yus, Anita, 2011) tentang standar pendidikan anak usia dini, menyebutkan ada 5 aspek yang perlu dikembangkan dalam pendidikan anak usia dini yaitu, aspek perkembangan kognitif, aspek perkembangan bahasa, aspek perkembangan moral agama, aspek perkembangan sosial-emosional dan aspek perkembangan fisik motorik.

PAUD merupakan salah satu jenjang yang paling strategis serta menentukan perjalanan dan masa depan anak secara keseluruhan, serta akan menjadi pondasi bagi penyiapan anak memasuki pendidikan 


\begin{tabular}{|l|l|r|}
\hline A1 Fitrah & \\
Journal Of Early Childhood Islamic Education & Pengembangan Nilai-nilai Kultur Positif \\
ISSN $:$ 2599-2287 & Pendidikan Anak Usia Dini Berbasis Islam \\
Vol.1 No.2 Januari 2018 & Buyung Surahman \\
\hline
\end{tabular}

dasar, menengah, dan pendidikan tinggi, bahkan akan mewarnai seluruh kehidupan nantinya di masyarakat. Oleh karena itu PAUD harus memperoleh perhatian yang layak dari berbagai pihak, baik keluarga, pemerintah, dan masyarakat. Pendidikan PAUD di Indonesia belum sesuai dengan harapan bangsa dibuktikan dengan data dari ketua himpunan PAUD (Neti Herawati, 2017) mengatakan hanya 23, 06\% pendidik PAUD stara strata-1, pembelajaran PAUD masih $\quad 80 \%$ baca-tulis-hitung, dan keterlibatan masyarakat belum sejalan dengan lembaga PAUD. Peningkatan mutu pendidikan diperlukan langkah-langkah dan tindakan nyata, sebagaimana dikemukakan oleh tim peneliti PPs UNY (2013: 1), ada dua strategi utama dalam memperbaiki dan mengembangkan kualitas sekolah yaitu: (1) fokus terhadap strategi struktural dan (2) fokus terhadap strategi kultural dengan tekanan pada perubahan perilaku.

Berdasarkan pengalaman yang cukup panjang strategi struktural kurang efektif dalam meningkatkan mutu Pendidikan Anak Usia Dini, sedangkan strategi kultural dari beberapa pendapat pakar berpengaruh besar terhadap perilaku belajar para siswa di sekolah Peterson (2002: 110). Hal ini dibuktikan dari hasil penelitian Stephen Stolp (1995) tentang Leadership for school culture, dari beberapa hasil studi menunjukkan kultur positif sekolah berkorelasi dengan peningkatan motivasi dan prestasi belajar serta kepuasan kerja dan produktivitas guru. Begitu juga, studi yang dilakukan Fyans dan Maehr (1997), pengaruh dimensi kultur positif sekolah dari survey terhadap 16.310 pendidikan anak usia dini, siswa kelas empat, enam, delapan, dan sepuluh dari 820 sekolah umum di Illinois, mereka lebih termotivasi dalam belajarnya dengan melalui kultur sekolah yang positif.

Salah satu upaya untuk menciptakan kultur yang positif di sekolah yaitu melalui pengembangan kultur sekolah. Sebagaimana dikemukakan oleh Spradley (1979: 73), ada beberapa kultur yang perlu dikembangkan dalam meningkatkan kualitas sekolah yaitu: behavior culture, artifacts culture, dan speech messages. Oleh karena itu di PAUD perlu dikembangkan kultur perilaku, artifak, pesan-pesan verbal, dan yang terkandung di dalamnya dalam meningkatkan mutu sekolah.

Depdiknas (2012: 9) menyebutkan sekolah yang berkulaitas di Indonesia yaitu sekolah yang menumbuhkembangkan kultur sekolah yang positif dalam meningkatkan kualitas sekolahnya. Terkait dengan hal tersebut, maka penelitian ini bertujuan untuk merumuskan bentuk 


\begin{tabular}{|l|l||r|}
\hline & Al Fitrah & Pengembangan Nilai-nilai Kultur Positif \\
Journal Of Early Childhood Islamic Education & Pendidikan Anak Usia Dini Berbasis Islam \\
ISSN : 2599-2287 & Buyung Surahman \\
\hline & Vol.1 No.2 Januari 2018 & \\
\hline
\end{tabular}

pengembangan nilai-nilai-nilai kultur positif di PAUD terakreditasi A di Bengkulu.

\section{Pengembangan Nilai-nilai Kultur PAUD}

Pengembangan kultur Pendidikan

Anak Usia Dini akan berkembang lebih baik jika terjalin hubungan yang baik sekolah-masyarakat, karena selain pemerintah juga masyarakat yang dapat membantu kemajuan sekolah. Strategi pengembangan kultur sekolah menurut pendapat Zamroni (2012: 31-39) dapat dilakuakan melalui tiga tataran yaitu: (1) pengembangan pada tataran sepirit dan nilai-nilai; (2) pengembangan pada tataran teknis; dan (3) pengembangan pada tataran sosial. Pengembangan pada tataran sosial ini merupakan proses implementasi dan institusionalisasi, seluruh kebijakan dan aturan teknis yang dikembangkan berdasarkan spirit nilai-nilai sehingga menjadi suatu kebiasaan (work habits) di sekolah dan di luar sekolah. Pendidikan anak usia dini memiliki peran yang sangat penting dalam pengembangan sumber daya manusia, untuk menurunkan fungsi-fungsi pendidikan anak usia dini dapat dilakukan melalui berbagai metode pembelajaran (Moeslichatoen, 2004:20).
Strategi pengembangan nilai-nilai sekolah, menurut pendapat Deal \& Kennedy (1985), dalam tiga tataran yaitu: pertama, tataran nilai, maksudnya, perubahan yang harus dilakukan adalah perubahan nilai-nilai lama yang menghambat nilai baru. Kedua, tataran praktek keseharian, transpormasi yang akan dilakukan adalah mengubah sikap dan perilaku lama yang bercirikan asal-asalan (asal mengajar, asal datang, dan asal jadi), menjadi sikap dan perilaku yang baru bercirikan kesungguhan dan dedikasi. Perilaku lama yang cenderung menunggu petunjuk dan berorientasi ke atasan, juga direformasi menjadi perilaku baru yang penuh inisiatif dan berorientasi kepada proses belajar siswa. Ketiga, tataran simbolsimbol kultur, perubahan yang harus dilakukan adalah mengganti simbol kultur yang konservatif dan sentralistik dengan simbol kultur yang dinamis. Perubahan simbol dapat dilakukan dengan mengubah penataan kelas dan ruang guru, serta pemasangan hasil karya siswa, foto-foto, dan moto.

Pada masa usia dini perlu menanamkan nilai-nilai moral, untuk perkembangan serta kecerdasan moral anak. Pendidikan moral diartikan sebagi suatu konsep kebijakan yang diberikan atau diajarkan kepada peserta didik untuk 


\begin{tabular}{|r||l|r|}
\hline Al Fitrah & Pengembangan Nilai-nilai Kultur Positif \\
Journal Of Early Childhood Islamic Education & Pendidikan Anak Usia Dini Berbasis Islam \\
ISSN : 2599-2287 & Buyung Surahman \\
\hline
\end{tabular}

membentuk budi pekerti luhur, berakhlak mulia dan berperilaku terpuji seperti tertuang dalam Pancasila dan UUD 1945. Nurul Zuriah (2007: 23) mengemukakan pendapat bahwa, pada jalur pendidikan non formal cara penanaman nilai moral pada anak usia dini bisa dilakukan melalui pendidikan keluarga dan pendidikan yang diselenggarakan oleh lingkungan. Seperti implementasinya jika bertemu dengan orang tua maka usia dini diajarkan: (1) memberikan salam dengan dengan tangan kanan; (2) mencium tangan kanan orang yang lebih tua; (3) mengucapkan salam; (4) bersikap sopan dan bicara dengan baik; dan (5) bila bicara harus memandang lawan bicara dengan pandangan yang sopan (Isjoni, 2009: 19-24).

Pengembangan kultur sekolah kurang lebih sama dengan pengembangan budaya organisasi lainnya. Harapan pengembangan budaya organisasi adalah menciptakan budaya unggul. Menciptakan budaya unggul menurut pendapat Cocld \& Piramid (2007: 58, 59) paling tidak ada tiga hal yang harus dilakukan yaitu: (1) mempunyai visi untuk unggul, untuk mewujudkan budaya unggul, visi akbar yang menggetarkan harus digerakkan; (2) memiliki kepemimpinan yang memberi contoh, kepemimpinan yang kompeten, profesional, dan inspiratif, harus memberi contah kepada karyawan; dan memperbaiki lingkungan organisasi, paradigma para pemimpin harus berubah sesuai dengan kondisi yang berubah.

Pendapat Cocld \& Piramid ini didukung oleh Kotter \& Heskett (1999: 94) yang mengatakan bahwa faktor yang unggul dalam pengembangan budaya adalah kepemimpinan yang kompeten, yang melakukan pengembangan dalam strategi, produk, struktur, kebijakan, personil dan budaya. Pengembangan kultur yang dapat meningkatkan kualitas organisasi antara lain perubahan perilaku organisasi. Dengan demikian, yang paling diutamakan dalam pengembangan kultur menurut pendapat Young Pai (2003: 209), yaitu bagaimana kultur bisa mengatur perilaku para anggota dalam mencapai tujuan organisasi, perilaku tersebut dilandasi oleh nilai-nilai, norma, aturan, dan keyakinan yang sudah disepakati oleh anggota organisasi.

Strategi pengembangan kultur positif sekolah menurut pendapat Zamroni (2012: 31-39), dapat dilakuakan melalui tiga tataran, yaitu sebagai berikut.

1) Pengembangan pada tataran sepirit dan nilai-nilai yang meliputi spirit dan nilai-nilai keimanan dan ketakwaan, keterbukaan, kejujuran, semangat hidup, belajar, menyadari diri sendiri dan keberadaan orang lain, untuk 


\begin{tabular}{|l|l|r|}
\hline & Al Fitrah & \\
Journal Of Early Childhood Islamic Education & Pengembangan Nilai-nilai Kultur Positif \\
ISSN : 2599-2287 & Pendidikan Anak Usia Dini Berbasis Islam \\
Vol.1 No.2 Januari 2018 & Buyung Surahman \\
\hline
\end{tabular}

selalu menghargai orang lain, persatuan dan kesatuan, untuk selalu bersikap dan prasangka positif, disiplin diri, tanggung jawab, dan kebersamaan.

2) Pengembangan pada tataran teknis yaitu (a) struktur organisasi sekolah; (b) deskripsi tugas sekolah; (c) tatatertib guru; (d) tatatertib siswa; (e) standar sistem pembelajaran yang harus diikuti guru dan siswa; (f) hubungan formal dan informal antara kepala sekolah, guru, dan tenaga kependidikan atau sesama guru dan tenaga kependidikan termasuk hubungan dengan siswa; (g) berbagai sanksi bagi siswa yang tidak jujur dan tidak disiplin; (h) berbagai program kerja dalam rangka membina keimanan dan ketakwaan siswa terhadap Tuhan Yang Maha Esa; (i) berbagai program kerja sekolah dalam rangka membiasakan siswa melakukan pemecahan masalah; (j) berbagai program ekstrakurikuler yang dapat menumbuhkembangkan kejujuran, kedisiplinan, rasa tanggung jawab, semangat hidup, persatuan dan kesatuan; (k) berbagai strategi belajar dan pembelajaran yang mendorong siswa agar semangat belajar; (l) berbagai aturan perawatan dan kebersihan fisik sekolah.

3) Pengembangan pada tataran sosial, pengembangan pada tataran sosial ini merupakan proses implementasi dan institusionalisasi, seluruh kebijakan dan aturan teknis yang dikembangkan berdasarkan spirit dan nilai-nilai sehingga menjadi suatu kebiasaan (work habits) di sekolah dan di luar sekolah.

Strategi pengembangan kultur sekolah, pendapat Deal \& Kennedy (2005), meniscayakan perubahan dalam tiga tataran. Pertama, tataran nilai, maksudnya perubahan yang harus dilakukan adalah perubahan nilai-nilai lama yang menghambat nilai baru. Nilai lama yang bercirikan nilai sedang-sedang saja ( mediocre values), seperti berpuas diri, tertutup, pasif, dan ketergantungan, harus diubah menjadi nilai baru yang bercirikan nilai keunggulan (excellent values), seperti terbuka terhadap inovasi, kompetitif, berinisiatif, independen, dan bertanggung jawab. Internalisasi nilai keunggulan ini sangat penting bagi keberhasilan mutu pendidikan. Harus adanya semangat untuk berinovasi, berkompetisi dan berani menanggung resiko.

Kedua, tataran praktik keseharian, transpormasi yang akan dilakukan adalah 


\begin{tabular}{|r||l|r|}
\hline Al Fitrah & Pengembangan Nilai-nilai Kultur Positif \\
Journal Of Early Childhood Islamic Education & Pendidikan Anak Usia Dini Berbasis Islam \\
ISSN : 2599-2287 & Buyung Surahman \\
Vol.1 No.2 Januari 2018 & \\
\hline
\end{tabular}

mengubah sikap dan perilaku lama yang bercirikan asal-asalan (asal mengajar, asal datang, dan asal jadi), menjadi sikap dan perilaku yang baru bercirikan kesungguhan dan dedikasi. Perilaku lama yang cenderung menunggu petunjuk dan berorientasi ke atasan, juga direformasi menjadi perilaku baru yang penuh inisiatif dan berorientasi kepada proses belajar siswa. Ketiga, tataran simbol-simbol kultur, perubahan yang harus dilakukan adalah mengganti simbol kultur yang konservatif dan sentralistik dengan simbol kultur yang dinamis. Perubahan simbol dapat dilakukan dengan mengubah penataan kelas dan ruang guru, serta pemasangan hasil karya siswa, foto-foto, dan moto.

Pengembangan kultur sekolah yang diharapkan mengarah kepada kultur yang positif (baik). Menurut pendapat Peterson dalam artikelnya (1998: 110), ada beberapa pedoman kultur yang dikatakan baik. Pertama, setiap pihak yang berkepentingan stakeholder memiliki kesepakatan tentang apa tujuan sekolah dan apa saja prinsip nilai-nilai yang berlaku di sekolah. Kedua, proses pembelajaran dan peningkatan mutunya berkesinambungan, dan mendukung program peningkatan profesionalisme pegawai tata usaha. Ketiga, menarik para guru dan pegawai tata usaha sekolah merasa bertanggung jawab terhadap proses pembelajaran yang mereka berikan kepada siswa. Keempat, suasana pergaulannya akrab, kolaboratif, saling berbagi ide positif, mereka bahu-membahu memperbaiki mutu sekolah. Kelima, program peningkatan profesionalisme sangat didukung, mereka berbagi informasi tentang praktik profesional mereka.

\section{Komponen- Komponen Pengembangan Kultur Positif di Sekolah}

Depdikbud (2012: 26,29,36,41) menyebutkan komponen-komponen yang mempengaruhi pengembangan kultur positif di sekolah antara lain yaitu: (1) komponen kepala sekolah, (2) komponen guru, (3) komponen siswa, (4) komponen pegawai tata usah. Spradley (1979: 73-76) menyebutkan komponen kultur yang mempengaruhi perkembangan kultur sekolah meliputi: (1) komponen kultur perilaku organisasi; (2) komponen kultur artifak; (3) komponen pesan-pesan verbal. Freire \& Achambault (1999: 490) mengemukakan bahwa, ada empat komponen yang mempengaruhi pengembangan kultur sekolah. Komponenkomponen tersebut yaitu: (1) pendidik, karena merupakan agen utama yang bertujuan, mengarahkan, memikul tanggung jawab atas proses pendidikan; (2) murid, yang menjadi objek upaya pendidikan 


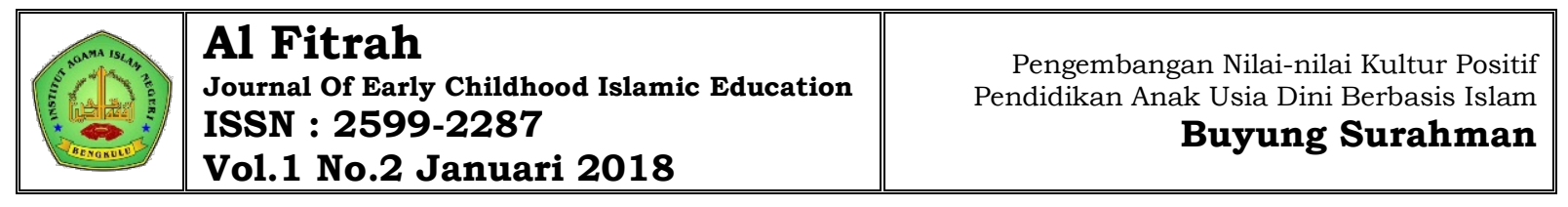

dalam arti perilakunya akan diubah, sikapsikapnya akan dipupuk dan dimudifikasi; (3) bahan pengajaran yang akan ditanamkan pada murid; dan (4) tujuan, sasaran, citacita, dan hasil akhir yang diharapkan sekolah. Dari beberapa pendapat di atas maka komponen-komponen yang mempengaruhi kultur sekolah yaitu: (1) komponen perilaku kepala sekolah, guru, siswa, dan pegawai tata usaha; (2) komponen kultur artifak meliputi dokumen, prestasi, benda/fasilitas sekolah; (3) komponen pesan-pesan verbal berupa tatatertib dan program sekolah; dan (4) komponen nilai-nilai yang terkandung dalam kultur perilaku, artifak, dan pesanpesan verbal.

Pengertian kultur yang positif sekolah didukung oleh hasil penelitian Cavanagh, Robert F (2015) The culture and improvement of Western Australia senior secondary schools. Penelitian tersebut terkait dengan efektivitas sekolah. Hasil penelitian tersebut menemukan bahwa hasil studi siswa merupakan konsekuensi nilai dan norma para staf sekolah. Nilai dan norma itulah yang membentuk pengembangan kultur sekolah dan menjadi pedoman mengajar para guru.

Oleh sebab itu, untuk memperbaiki kualitas sekolah diperlukan kultur sekolah yang positif yaitu sebagai berikut. Pertama, perbaikan kultur perilaku kepala sekolah, guru, siswa, dan pegawai tata usaha. Kedua, perbaikan kultur artifak berupa dokumen, prestasi, dan benda. Ketiga, perbaikan pesan-pesan lisan berupa aturan/tatatertib, program sekolah. Keempat, perbaikan nilainilai yang terkandung dalam kultur perilaku, artifak, dan pesan-pesan lisan. Menurut pendapat Deal dan Peterson (2002), kekuatan yang bisa diambil dari kultur sekolah adalah membangun sekolah lebih hidup, semangat, kooperatif, dan penghayatan akan identitas sekolah.

Salah satu indikator sekolah yang berkualitas antara lain memiliki budaya yang baik dan unggul. Kotter \& Heskett (1992: 31) mengemukakan bahwa sebuah budaya itu baik hanya jika "cocok” dengan konteksnya. Menurut pendapat Cocld \& Piramid (2007: 62), budaya unggul dikatakan kuat apabila nilai-nilai budaya itu sendiri dipahami dan diikuti, serta dilaksanakan sebagian besar oleh sumber daya manusia di organisasi tersebut.

Spradley (1979: 11) menuliskan yang mempengaruhi perkembangan kultur meliputi komponen: (1) perilaku budaya (cultural behavior); (2) artifak budaya (cultural artifacts); dan (3) pesan-pesan verbal (speech message). 


\begin{tabular}{|l|l|r|}
\hline Al Fitrah & Pengembangan Nilai-nilai Kultur Positif \\
Journal Of Early Childhood Islamic Education & Pendidikan Anak Usia Dini Berbasis Islam \\
ISSN $:$ 2599-2287 & Buyung Surahman \\
Vol.1 No.2 Januari 2018 & \\
\hline
\end{tabular}

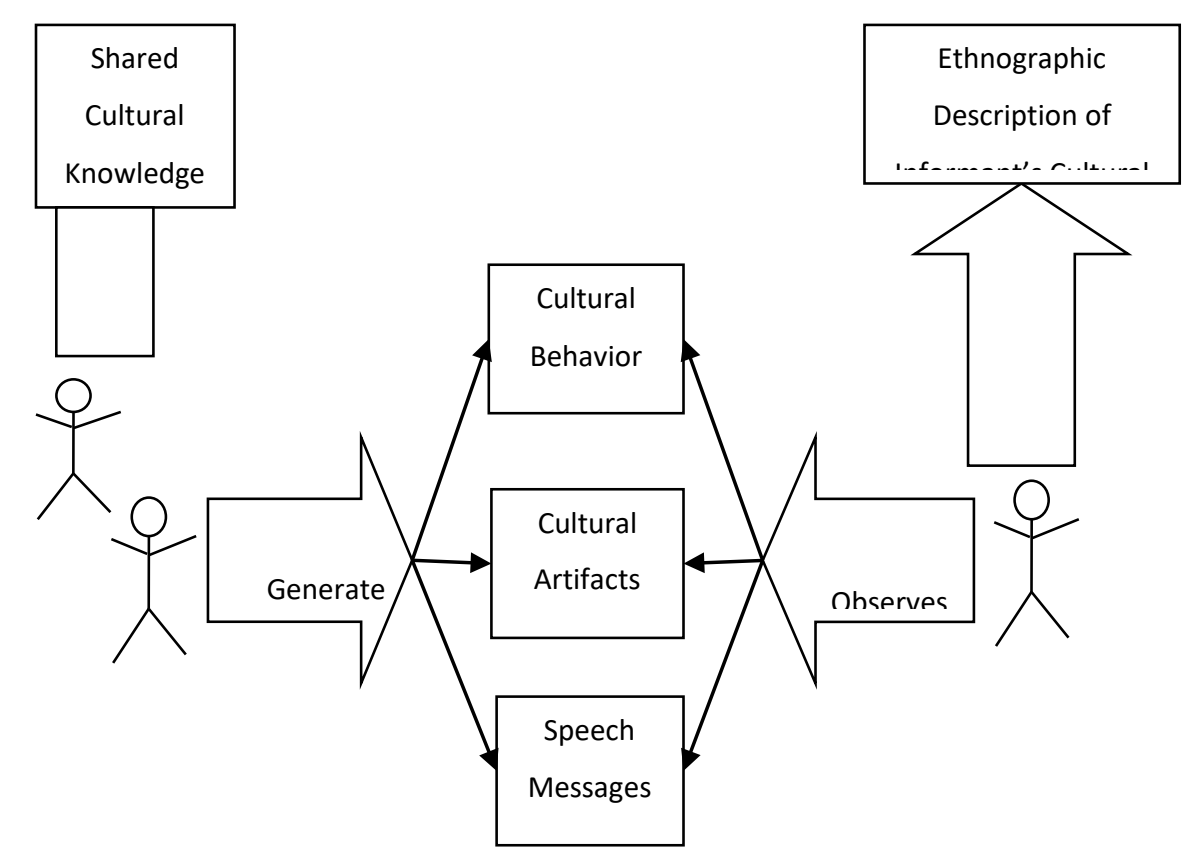

Gambar 1. Making Cultural Interences

Sumber: Spradley (1980: 11).

Komponen-komponen yang

memepengaruhi nilai-nilai kultur positif sekolah dapat dijelaskan berikut ini.

a. Nilai-nilai Kultur Positif Kepala Sekolah

Depdiknas (2012: 21-63) menyebutkan bahwa ada beberapa tugas/peran/ tanggung jawab kepala sekolah dalam mewujudkan kualitas sekolah. Pertama, kepala sekolah perlu memiliki strategi yang tepat untuk mencapai visi, misi, tujuan, dan target sekolah. Kedua, kepala sekolah bisa membawa kesan positif dalam mempengaruhi bawahan atau orang lain. Ketiga, kepala sekolah mampu memobilisasi sumber daya yang ada dilingkungannya. Keempat, kepala sekolah mampu mengambil keputusan secara trampil (cepat, tepat, dan cekat). Kelima, kepala sekolah bisa mendorong melakukan inovasi sekolah. Keenam, kepala sekolah mampu menggalang team work yang kompak, cerdas, dan dinamis. Ketujuh, kepala sekolah mendorong kegiatan yang bersifat kreatif. Kedelapan, kepala sekolah menciptakan sekolah sebagai learning organization.

Nilai-nilai yang perlu dimiliki oleh pemimpin antara lain: (1) integritas dan moralitas. Integritas menyangkut mutu, sifat dan keadaan yang menunjukkan kesatuan yang utuh sehingga memiliki 


\begin{tabular}{|l|l|r|}
\hline & Al Fitrah & \\
Journal Of Early Childhood Islamic Education & Pengembangan Nilai-nilai Kultur Positif \\
ISSN : 2599-2287 & Pendidikan Anak Usia Dini Berbasis Islam \\
Vol.1 No.2 Januari 2018 & Buyung Surahman \\
\hline
\end{tabular}

potensi dan kemampuan yang memancarkan kewibawaan dan kejujuran. Moralitas menyangkut akhlak, budi pekerti susila, dan ajaran tentang baik dan buruk; (2) keteladanan adalah sikap dan tingkah laku yang dapat menjadi contoh bagi orang-orang yang dipimpinnya, keteladanaan berkaitan erat dengan kehormatan, integritas, dan moralitas pemimpin; (3) menjaga kehormatan, seorang pemimpin harus menjaga kehormatan dengan tidak melakukan perbuatan tercela karena perbuatannya menjadi contoh bawahannya; dan (4) nilai kebijaksanaan, yaitu kearifan pimpinan dalam memutuskan sesuatu sehingga keputusan adil dan bijaksana

Selain nilai-nilai yang harus dimiliki seorang pemimpin, etika yang baik ahrus juga dimiliki. Etika merupakan perilaku berstandar normatif berupa nilai-nilai moral, norma-norma, dan halhal yang baik. Adapun etika dalam kepemimpinan yakni: menjaga perasaan orang lain, memecahkan masalah dengan rendah hati, menghindari pemaksaan kehendak tetapi menghargai kehendak orang lain, mengutamakan proses dialogis dalam memecahkan masalah, menanggapi masalah dengan cepat, mengedepankan sikap jujur, disiplin dan dapat dipercaya.

b. Komponen Guru

Nilai-nilai kultur positif yang harus dimiliki guru antara lain: (1) keteladanan, adalah sikap dan tingkah laku yang dapat menjadi contoh bagi anak didiknya ataupun orang-orang disekitarnya; (2) tanggung jawab, guru harus memikul tanggung jawab untuk menjalankan tugas yang dipercayakan kepadanya; (3) integritas dan moralitas, integritas menyangkut mutu, sifat dan keadaan yang menunjukkan kesatuan yang utuh sehingga memiliki potensi dan kemampuan yang memancarkan kewibawaan dan kejujuran. Moralitas menyangkut akhlak, budi pekerti susila, dan ajaran tentang baik dan buruk; (4) nilai kebaikan, yaitu nilai ini mengarahkan guru agar berbuat baik, baik dari kata-kata, tingkah laku, dan perbuatan; dan (5) nilai sikap terhadap siswa, yaitu guru dekat dan peduli pada siswa, guru merasa sebagai oang tua siswa, dan guru sebagai pemimbing siswa.

Menurut pendapat Maslow (1954) dikutip oleh Parkay \& Stanford (2008: 116, 117) bahwa orientasi psikologis, guru seharusnya tidak memaksa para murid untuk belajar. Sebaliknya, 


\section{\begin{tabular}{|l|l|}
\hline & A1 Fitrah \\
Journal Of Early Childhood Islamic Education \\
ISSN : 2599-2287 \\
Vol.1 No.2 Januari 2018 \\
\hline
\end{tabular}}

mereka perlu membuat suatu iklim kepercayaan dan saling hormat yang memungkinkan para murid menentukan apa dan bagaimana mereka belajar, untuk mempertanyakan suatu kebijakan, dan untuk mengambil inisiatif dalam membuat diri mereka sendiri. Guru perlu menjadi fasilitator, dan ruang kelas seharusnya menjadi tempat “dimana rasa ingin tahu dan hasrat diri untuk belajar dapat dipupuk dan diperkuat”

Guru dalam mengajar perlu memiliki beragam metode di antaranya pengajaran konstruktivisme. Parkay \& Stanford dkk. (2008: 449, 452) mengemukakan pendapatnya bahwa salah satu metode belajar yang efektif berdasarkan perkembangan anak pada pengajaran konstruktivisme adalah sebagai berikut. Pertama, guru memancing pengetahuan siswa sebelumnya dan ini merupakan sebagai titik awal pengajaran. Kedua, guru tidak hanya menyajikan materi pada siswa, tetapi juga memproses usaha siswa untuk mempelajari materi. Ketiga, guru menciptakan lingkungan sosial dalam kelas, sebuah komunitas pelajar, yang mengizinkan siswa merefleksikan dan bicara dengan yang lain saat mereka menyelesaikan masalah. Keempat,

Guru disarankan oleh Martin Heidegger dalam Palmer (2001: 48), hendaknya menjalin hubungan yang simpatik dan bersikap terbuka dengan anak didik, namun bukan dengan cara menuruti kehendaknya, melainkan lebih memicu semangat atau motivasi yang menantang dalam belajar, apa yang perlu ditawarkan pada anak dalam mata pelajaran, dan apa yang menjadi persoalan penting bagi anak didik dalam belajar. Oleh sebab itu, menurut pendapat Philip, Gail, dan Lois (1985: 236) bahwa guru harus bisa membaca, menulis, berhitung, dan mempunyai pengetahuan sosial yang wajar. Guru perlu skil, mempunyai strategi yang banyak, menguasai manajemen kelas, dan bisa mencari solusi problem.

Untuk meningkatkan kualitas sekolah, guru perlu dibekali pendidikan dan pelatihan. Horace Mann (17961849) dalam Parkay \& Stanford, et al. (2008: 128) berpendapat bahwa para guru perlu memperoleh pendidikan dan pelatihan secara komprehensif dengan program profesional. Program pelatihan guru hendaknya tidak hanya perilaku 


\begin{tabular}{|l|l|r|}
\hline & Al Fitrah & \\
Journal Of Early Childhood Islamic Education & Pengembangan Nilai-nilai Kultur Positif \\
ISSN : 2599-2287 & Pendidikan Anak Usia Dini Berbasis Islam \\
Vol.1 No.2 Januari 2018 & Buyung Surahman \\
\hline
\end{tabular}

manajemen, tetapi juga terkait dengan perilaku pengajaran. Pendapat Horace Mann ini didukung oleh hasil penelitian Doyle (1986) dalam Depdiknas (2002) yang menyebutkan bahwa perilaku manajemen tidak hanya meliputi manajemen, organisasi dan pengaturan kelas, tetapi juga perilaku pengajaran. Oleh sebab itu, Creemers \& Kaluge (2005: 8) mengatakan proses pembelajaran menekankan pendidikan dalam ruang kelas yang terutama dipengaruhi perilaku guru.

Di samping itu, dalam mewujudkan kualitas sekolah guru perlu memiliki profesional yang tinggi. Untuk menuju profesional hendaknya guru mengetahui apa dan bagaimanan propesional tersebut. Menurut pendapat Parkay \& Stanford (2008: 175) guru yang profesionalismenya tinggi adalah sebagai berikut. Pertama, peduli dengan kesejahteraan murid-muridnya dan mewakili mereka jika diperlukan. Kedua, membina hubungan dengan rekan kerja di sekolah, orang tua murid, serta agen-agen di lingkungan komunitas yang lebih besar untuk mendukung pembelajaran berkualitas dan pertumbuhan murid. Ketiga, guru memahami bagaiman faktor di lingkungan luar sekolah murid (misalnya, keadaan keluarga, lingkungan masyarakat, kondisi kesehatan dan ekonomi), karena hal seperti ini dapat mempengaruhi kehidupan dan pembelajaran murid.

c. Komponen Siswa

$$
\text { Pendapat John Dewey (1902) }
$$

dalam Parkay \& Stanford (2008: 135) diyakini bahwa perkembangan mental, fisik, dan spritual anak dapat ditingkatkan dengan memberikan aktivitas pendidikan yang sesuai. Penelitian Montessori mempraktikkan materi latihan fisik digunakan untuk mengembangkan pengetahuan dan kemampuan murid dengan materi yang sesuai, dan ternyata hasilnya materi tersebut merangsang minat para murid dan minat akan motivasi mereka untuk belajar. Oleh karena itu, Farkay \& Stanford (2008: 391) mengatakan guru perlu memahami gaya belajar muridmurid, dan memotivasi dan membantu gaya belajar mereka, sehingga dengan bantuan guru dan orang lain setiap murid dapat mengembangkan strategi keahlian dalam pembelajaran sesuai dengan minat mereka.

Salah satu usaha dalam meningkatkan prestasi siswa belajar, yaitu siswa perlu diberi motivasi. Untuk memotivasi siswa belajar antara lain 


\begin{tabular}{|l|l|r|}
\hline A1 Fitrah & $\begin{array}{r}\text { Pengembangan Nilai-nilai Kultur Positif } \\
\text { Journal Of Early Childhood Islamic Education } \\
\text { ISSN }: \text { 2599-2287 }\end{array}$ \\
Vol.1 No.2 Januari 2018 & Pendidikan Anak Usia Dini Berbasis Islam \\
\hline
\end{tabular}

guru perlu menemukan gaya belajar yang baik, seperti yang dikatakan Jerome Bruner (1966) yang dikutip oleh Ratna Wilis Dahar (1988: 125) bahwa belajar penemuan (discovery learning) sesuai dengan pencarian pengetahuan secara aktif oleh manusia, dan dengan sendirinya memberikan hasil yang paling baik. Oleh sebab itu, Bruner menyarankan agar siswa belajar melalui berpartisipasi secara aktif dengan konsep-konsep dan prinsip-prinsip, sehingga mereka dianjurkan untuk memperoleh pengalaman, dan melakukan eksperimen-eksperimen yang mengizinkan mereka untuk menemukan prinsip-prinsip itu sendiri.

Di samping belajar dengan menggunakan metode yang baik, siswa juga perlu disiplin dalam belajar. Dikemukakan oleh Geoff Colvin (2008: 10) bahwa sarana mendasar yang memungkinkan tujuan-tujuan sekolah tercapai, khususnya tujuan-tujuan pencapaian prestasi murid yaitu disiplin. Oleh karena itu, salah satu kriteria siswa berkualitas adalah disiplin dalam belajar. Wien Sukarsih (2004: 7) mengatakan bahwa siswa perlu disiplin dalam meningkatkan kualitas sekolah, yaitu disiplin dalam belajar, berpakaian, membuat tugas, waktu masuk/keluar kelas, disiplin waktu upacara, dan lainlain.

Untuk meningkatkan kualitas sekolah, tidak cukup hanya kegiatan belajar bagi siswa, tetapi juga ditunjang oleh yang lain, seperti yang dikatakan Kent Peterson (2002: 111) bahwa yang menunjang kualitas sekolah, yaitu (1) pergaulan siswa yang akrab, kolaboratif, saling bagi ide positif, mereka saling bahu-membahu memperbaiki kualitas sekolah; (2) mereka berbagi informasi tentang praktik profesional; dan (3) program pembelajaran mereka berkesinambungan; serta (4) guru, siswa, dan staf memiliki kesepakatan tentang apa tujuan sekolah itu dan apa saja prinsip nilai yang berlaku di sekolah. Namun, dalam memecahkan masalah pembelajaran siswa perlu saling membantu. Oleh sebab itu, Farkay \& Stanford (2008: 190) mengatakan untuk membantu siswa belajar, siswa secara berkelompok berteman dalam memecahkan masalah pembelajaran.

Siswa yang memperoleh pengetahuan dan keterampilan dalam belajar, berarti menunjukkan peningkatkan kualitas sekolah. Hal ini didukung oleh hasil penelitian Creemers \& Kaluge (2005: 131) yang mengatakan 


\begin{tabular}{|l|l|r|}
\hline & Al Fitrah & \\
Journal Of Early Childhood Islamic Education & Pengembangan Nilai-nilai Kultur Positif \\
ISSN : 2599-2287 & Pendidikan Anak Usia Dini Berbasis Islam \\
Vol.1 No.2 Januari 2018 & Buyung Surahman \\
\hline
\end{tabular}

bahwa hasil penelitian 400 sekolah berkualitas di Amerika Serikat dengan kesimpulan sebagai berikut. Pertama, sekolah mempunyai iklim dan budaya yang produktif. Kedua, sekolah memfokuskan perolehan (pengetahuan) siswa dalam hal keterampilan belajar. Ketiga, sekolah membantu kemajuan siswa secara berkala. Keempat, kepemimpinan yang bagus. Kelima, orientasi pengembangan staf pada hal praktis di sekolah. Keenam, penyusunan dan pelaksanaan pengajaran yang efektif. Ketujuh, ekspektasi yang tinggi terhadap prestasi siswa. Kedelapan, kemungkinan korelasi yang lain.

d. Komponen Pegawai Tata Usaha

Dalam upaya mencapai kemajuan sekolah, Kemendiknas (2012: 17) menyebutkan unsur tenaga teknis, mencakup pustakawan, laboran, tenaga bengkel, pegawai tata usaha perlu diberdayakan, sehingga kualitas kemampuan mereka dapat diandalkan. Pendidikan dan pelatihan sering digunakan untuk meng-upgrade kemampuan mereka, tetapi pada perinsipnya tenaga teknis ini akan lebih berdaya jika mereka diberi kepercayaan. Kaagan (2008: 4) mengatakan untuk menjadikan staf professional mereka perlu melakukan pelatihan, mereka perlu melakukan saling belajar, dan bagaimana melakukan pekerjaan mereka dengan cara yang lebih baik.

Untuk menjadikan staf yang profesional, sekolah perlu memiliki budaya yang positif, seperti yang dikatakan oleh Cocld \& Piramid (2007: 202, 203) ada lima tahapan mencapai budaya yang berdampak positif, yaitu dipaksa, terpaksa, bisa, biasa, dan budaya. Tahap pertama dipaksa, disadari bahwa salah satu unsur pembentuk perubahan perilaku adalah adanya sistem yang dapat memaksa seseorang atau kelompok untuk tunduk kepada aturan. Tahap kedua terpaksa, melalui sistem yang telah ditetapkan, para karyawan baik dengan kesadaran maupun keterpaksaan akan rela mengikutinya. Tahap ketiga bisa, kebiasaan seseorang baik melalui pelatihan ataupun melalui coaching dikaitkan dengan sistem yang berlaku dalam organisasi. Tahap keempat biasa, kebiasaan yang terus menerus, dipantau diperbaiki sesuai dengan perubahan lingkungan yang akan menjadi kebiasaan bekerja. Tahap kelima budaya, kebiasaan yang rutin dan sering dinyatakan dan disertai apersiasi diharapkan menjadi budaya kerja yang 


\begin{tabular}{|l|l|r|}
\hline A1 Fitrah & $\begin{array}{r}\text { Pengembangan Nilai-nilai Kultur Positif } \\
\text { Journal Of Early Childhood Islamic Education } \\
\text { ISSN }: \text { 2599-2287 }\end{array}$ \\
Vol.1 No.2 Januari 2018 & Pendidikan Anak Usia Dini Berbasis Islam \\
\hline
\end{tabular}

merupakan komponen pembentuk budaya organisasi. Kotter \& Koter \& Heskett (1992: 18) mengatakan salah satu indikator kinerja yang berkualitas yaitu rasa komitmen terhadap tugas.

Untuk meningkatkan perbaikan proses pendidikan, pegawai tata usaha sekolah perlu meningkatkan kinerjanya. Salah satu peningkatan kinerja pegawai tata usaha yaitu meningkatkan komitmen, kualitas, dan kinerja keseharian staf (Preedy, 1993: 46). Implementasi komitmen dengan pekerjaan maka staf datang dan pulang tepat waktu, meningkatkan pelayanan terhadap warga sekolah, melakukan kerja sama yang baik antar staf, dan melakukan tugas dengan tepat waktu. Kotter \& Haskett (1992: 18) mengatakan rasa komitmen atau loyal dikatakan membuat orang berusaha lebih keras.

Di samping itu, untuk menunjang perbaikan proses belajar mengajar perlu peningkatan pelayanan pegawai tata usaha. Pegawai tata usaha perlu skil yaitu memiliki keahlian yang dibutuhkan dalam mewujudkan kinerja. Menurut pendapat Cocld \& Piramid (2007: 164), untuk memajukan organisasi, staf diperlukan teamwork, yaitu mengutamakan kerja sama tim untuk menghasilkan sinergi yang optimal; (2) innovative, yaitu berpikir dan bertindak kreatif; (3) excellent, yaitu bekerja keras untuk menghasilkan kinerja yang sesuai dengan potensi individu; (4) proaktif, yaitu mengambil inisiatif pada saat menghadapi resiko yang mungkin terjadi; dan (5) responsible, yaitu memiliki rasa tanggung jawab atas keputusan yang diambil dan/ atau tindakan yang telah diambil.

e. Komponen Aturan/Tata Tertib

$$
\text { Depdiknas （2012: }
$$

mengatakan bahwa tatatertib sekolah merupakan seperangkat peraturan yang harus ditaati dan dilaksankan oleh siswa, serta dimaksudkan sebagai rambu-rambu bagi siswa dalam bersikap, berucap, bertindak dalam melaksankan kegiatan sehari-hari di sekolah. Tujuan tata tertib sekolah di antaranya adalah untuk mengatur kehidupan sekolah sehari-hari sehingga tujuan pendidikan tercapai. Selanjutnya tata tertib sekolah untuk menciptakan kondisi belajar yang kondusif, mengarahkan tingkah laku dan sikap siswa, dan mempererat persatuan dan kesatuan warga sekolah.

Aturan sekolah yang bermutu adalah aturan sekolah yang sederhana 


\begin{tabular}{|l|l|r|}
\hline & Al Fitrah & \\
Journal Of Early Childhood Islamic Education & Pengembangan Nilai-nilai Kultur Positif \\
ISSN : 2599-2287 & Pendidikan Anak Usia Dini Berbasis Islam \\
Vol.1 No.2 Januari 2018 & Buyung Surahman \\
\hline
\end{tabular}

dan jelas tentang hak dan kewajiban, apa yang boleh dan tidak boleh dilakukan, reward dan punishment yang jelas, serta aturan tersebut dilaksanakan secara konsekuen (Depdiknas, 2012: 32). Komponen aturan/tata tertib sangat berguna bagi siswa, guru, dan pegawai tata usaha, karena aturan/tata tertib merupakan rambu-rambu siswa, guru, dan pegawai tata usaha dalam melakukan tugas di sekolah. Oleh karena itu, semua sekolah perlu mempunyai aturan/tata tertib.

Aturan/tatatertib berguna bagi siswa, guru, dan pegawai tata usaha untuk menunjang kelancaran tugas mereka. Jika sekolah tidak memiliki tata tertib, sekolah tersebut akan kacau dan tidak aman karena tidak ada ramburambu atau aturan dalam berucap, bersikap, dan berbuat di sekolah. Oleh karena itu, di sekolah perlu dibuat aturan/tata tertib dan ditaatinya.

\section{Metodologi Penelitian}

Jenis penelitian ini adalah penelitian kualitatif yang menggunakan pendekatan naturalistik, pendekatan ini dipilih karena cocok dalam mendeskripsikan kultur sekolah yang berhubungan dengan pengembangan nilai-nilai kultur positif pada Pendidikan Anak Usia Dini. Penelitian dilakukan tiga sekolah Pendidikan Anak Usia Dini terakreditasi A di Bengkulu. Pengumpulan data menggunakan teknik dokumentasi, observasi, dan wawancara. Data pengembangan niali-nilai kultur positif dianalisis dengan analisis domain, taksonomi, komponensial, dan analisis tema kultural, yang mengacu pada buku Spradley (1979).

\section{Hasil Temuan}

Berdasarkan hasil temuan penelitian menunjukkan bahwa, bentuk dan cara Pendidikan Anak Usia Dini mengembangkan nilai-nilai kultur positif di sekolah sebagai berikut:

\section{Nilai Keimanan}

Nilai keimanan dan ketaqwaan siswa di sekolah dikembangkan melalui antara lain: siswa membiasakan mengucapkan salam dan membalas salam baik ketika anak datang maupun pulang, anakanak bersama guru melakukan shalat dhuha mulai hari senin sampai kamis setiap minggu, anakanak membaca doa mau makan dan sesudah makan, anak-anak membaca doa waktu ke kamar mandi atau kakus dan naik kendaraan, dan memperingati harihari besar Islam. 


\begin{tabular}{|l|l|r|}
\hline A1 Fitrah & $\begin{array}{r}\text { Pengembangan Nilai-nilai Kultur Positif } \\
\text { Journal Of Early Childhood Islamic Education } \\
\text { ISSN }: \text { 2599-2287 }\end{array}$ \\
Vol.1 No.2 Januari 2018 & Pendidikan Anak Usia Dini Berbasis Islam \\
\hline
\end{tabular}

2. Pengambangan nilai kejujuran siswa antara lain yaitu, siswa membiasakan jika siswa menemukan barang orang lain di sekolah dikembalikan kepada yang bersangkutan atau melalui guru, siswa jujur dalam melakukan piket kelas, dan siswa jujur dalam berbicara baik terhadap guru, teman, dan orang lain.

3. Nilai Keterbukaan

Nilai keterbukaan siswa dikembangkan melalui antara lain: siswa membiasakan dalam pergaulan sehari hari terbuka yaitu ramah, saling membantu, saling tukar informasi. Pada waktu bicara siswa terbuka baik dalam mengeluarkan pendapat maupun menerima pendapat. Siswa bebas bergaul dan tidak membedakan suku, ras, status pekerjaan orang tua, dan status ekonomi.

4. Nilai Semangat Hidup

Pengembangan nilai semangat hidup siswa antara lain yaitu, membiasakan melalui pelaksanaan 7K (keamanan, ketertiban, kesehatan, kerindangan, kebersihan, kerapihan, dan keindahan). 7K menunjukkan semangat hidup bagi siswa, karena sekolah mereka aman, tertib, bersih, nyaman, indah, rindang dan rapi, hal ini membuat siswa senang datang ke sekolah. Jika siswa merasa senang datang ke sekolah berarti siswa telah menunjukkan semangat hidup. Lingkungan sekolah yang bersih nyaman, aman, rapi, indah, dan rindang, siswa juga mengenakan pakain rapi, bersih, dan rambut rapi.

5. Spirit Nilai Belajar

Pengembangan spirit nilai belajar siswa di sekolah antara lain: siswa membiasakan belajar di kelas serius, tekun, konsentrasi, dan sering bertanya. Waktu jam istirahat sebagian besar melakukan kegiatan di taman bermain.

6. Nilai Menyadari Diri

Nilai menyadari diri sendiri dan keberadaan orang lain dikembangkan antara lain: (1) siswa memiliki pola hidup sederhana, siswa tidak disuruh membawa uang banyak ke sekolah, tidak membawa perhiasan emas ke sekolah; (2) peduli terhadap orang lain, jika ada yang musubah semua siswa melakukan kunjungan terhadap yang musibah; (4) nilai untuk selalu menghargai orang lain dikembangkan di sekolah antara 


\begin{tabular}{|l|l|r|}
\hline & Al Fitrah & \\
Journal Of Early Childhood Islamic Education & Pengembangan Nilai-nilai Kultur Positif \\
ISSN : 2599-2287 & Pendidikan Anak Usia Dini Berbasis Islam \\
Vol.1 No.2 Januari 2018 & Buyung Surahman \\
\hline
\end{tabular}

lain: siswa tidak melecehkan orang lain, peduli terhadap orang lain.

Siswa tidak egoisme, tidak sombong, dan tidak saling memotong pembicaraan waktu sedang bicara; dan (4) saling berbagi makanan.

7. Siswa memiliki tata krama yang baik yaitu sopan, santun, menghargai orang lain, dan hati-hati dalam bersikap, berucap, dan bertindak.

8. Nilai Persatuan dan Kesatuan

Pengembangan nilai persatuan dan kesatuan siswa antara lain: siswa memiliki nilai persatuan dan kesatuan dalam menjaga kebersihan dan keamanan sekolah, siswa saling membantu dalam kesulitan seperti siswa membantu yang ekonomi lemah jika mengumpul uang untuk kemajuan kelas. Jika ada siswa ditimpa musibah seperti siswa rumahnya kebakaran, atau ada siswa yang masuk rumah sakit karena sakit, maka siswa yang lain berkunjung membantu, ikut berduka cita dan berdoa.

9. Nilai Sikap

Pengembangan nilai untuk selalu bersikap dan prasangka positif pada siswa di sekolah antara lain: siswa tidak iri hati atau dengki terhadap orang lain. Kemudian siswa tidak mudah menuduh orang lain, siswa saling menghargai dan menghormati, siswa bersikap, berucap sesuai dengan perbuatan, dan siswa bertindak sesuai dengan aturan. Selanjutnya siswa menuruti nasehat guru tentang nilai untuk selalu bersikap dan prasangka positif terhadap orang lain.

10. Nilai Disiplin

Pengembangan nilai disiplin siswa melalui, siswa jarang melanggar tatatertib. Seperti siswa jarang terlambat masuk kelas, siswa jarang terlambat mengikuti upacara bendera pada hari Senin, dan siswa jarang mengerjakan PR mencontoh dengan teman di sekolah. Di samping itu siswa selalu mentaati tatatertib berpakian waktu ke sekolah, seperti siswa mengenakan pakaian sekolah bahannya, warna dan model sesuai dengan aturan yang ditetapkan sekolah. Kemudian siswa selalu disiplin waktu belajar di kelas, siswa tekun, tidak ribut, tidak keluar kalau bukan ada kepentingan dan jika ada kepentingan siswa izin dengan guru. 11. Nilai Tanggung Jawab 


\begin{tabular}{|r||l|r|}
\hline Al Fitrah & Pengembangan Nilai-nilai Kultur Positif \\
Journal Of Early Childhood Islamic Education & Pendidikan Anak Usia Dini Berbasis Islam \\
ISSN : 2599-2287 & Buyung Surahman \\
\hline
\end{tabular}

Pengembangan nilai tanggung jawab siswa antara lain: siswa bertanggung jawab dengan kebersihan kelas, yaitu kelas bersih karena siswa ada yang piket kelas, kemudian siswa tidak membuang sampah sembarangan di kelas. Tanggung jawab dengan keamanan kelas, siswa tidak kehilangan barang di kelas, karena semua siswa mengamankan kelas. Tanggung jawab jika di suruh guru tampil ke depan kelas untuk memperagakan sesuatu.

12. Nilai Kebersamaan

Pengembangan nilai kebersamaan bagi siswa antara lain: siswa kebersamaan dalam menjaga ketertiban sekolah, siswa kebersamaan dalam memberi petunjuk kepada teman yang belum menguasai materi pelajaran yang dijelaskan oleh guru. Siswa kebersamaan dalam membantu panti-panti, bencana gempa, dan banjir, kebakaran. Siswa kebersamaan dalam memberi spirit setiap timnya bertanding, supaya timnya dapat memenangkan pertandingan.

\section{Kesimpulan}

Berdasarkan hasil temuan peneliti bahwa, pengembangan niali-nilai kultur positif yang dilakukan oleh kepala sekolah, guru, pegawai tata usaha, dan siswa antara lain: nilai keimanan, semangat hidup, keterbukaan, kejujuran, spirit belajar, menyadari diri, tata krama, persatuan dan kesatuan, nilai sikap, disiplin, tanggung jawab, dan kebersamaan. Pengembangan nilai-nilai ini dibungkus dan diterapkan oleh siswa dan guru di lingkungan sekolah, sehingga membuat sekolah bercirikan Islami ini maju dan berkembang dan dicintai oleh masyarakat.

\section{DAFTAR PUSTAKA}

Cavanagh, Robert, F. (1997). The culture and improvement of Western Australia senior secondary schools. Disertasi tidak diterbitkan. Curtin University of Technology CRICOS Provider Code 00301J.

Cocld., \& Red Piramid. (2007). Corporate culture challenge to excellence. (Terjemahan Djokosantoso Meoljono \& Steve Sudjatmiko). New york. (Buku aslinya diterbitkan tahun 2007).

Creemers, B. P. M., dan Kaluge, L. (2005). Teori dan praktek keefektifan pendidikan. (Terjemahan Tim Unesa University Press). Netherlands. (Buku asli diterbitkan tahun 1994).

Deal, Terrence E., dan Kent D. Peterson. (1985). The school culture, California: Jossey- Bass Publisher Kemendikbud, (2012). Memahami budaya sekolah. 


\begin{tabular}{|l|l|r|}
\hline & Al Fitrah & \\
Journal Of Early Childhood Islamic Education & Pengembangan Nilai-nilai Kultur Positif \\
ISSN : 2599-2287 & Pendidikan Anak Usia Dini Berbasis Islam \\
Vol.1 No.2 Januari 2018 & Buyung Surahman \\
\hline
\end{tabular}

kultur sekolah.

(2012). Pedoman pengembangan

Douglas, H. (1994). Schools of hope: Developing mind and character in todays youth. San Prancisco, California: Jossey- Bass Publisher.

DurBin, A. J. (2005). The complete ideal's guide leadership. (Terjemahan Tri Wibowo Budi Santoso). New York. (Buku asli diterbitkan tahun 2000).

Farida Samad \& Bujana Alhadad. (2016). Penelitian berjudul Implimentasi Metode Beyond Center and Circle Time (BCCT) dalam Upaya Penanaman Nilai-nilai Agama Islam di Kelompok B Taman Kanak-kanak Khalifah Kota Ternateh, dalam Jurnal Pendidikan Usia Dini, Volome 10 Edisi 2, November 2016.

Firth, R. (1958). Human types an introduction to social anthropology. London: A Mentor Book.

Freire, P. (1985). Pendidikan kaum tertindas. (Terjemahan Utomo Dananjaya, Mansour Fakih., et al). New York (Buku asli diterbutkan tahun 1972).

Freire, P., Archambault., et al. (1999). Menggugat pendidikan. (Terjemahan Omi Intan Naomi). New York. (Buku asli diterbitkan tahun 1997).

Gerstner, L. V., Semerad, R. D., et al. (1994). Reinventing education. New York: A Plume Book.

Geoff Colven. (2008). Seven steps developing a proactive schoolwide discipline plan. Boston: Pearson.

Glasser, W. (1992). The quality school. New York: Harper Perennial.

Haviland, W. A. (1983). Cultural anthropology. New York: Holt, Rinehart and Winston.
Kaagan, S. S. (2008). 30 reflective staff development exercises for educator. Boston: Reason.

Kotter, J. P., \& Heskett, J. L. (1999). Corporate culture and performance. (Terjemahan Benyamin Molan). New York. (Buku asli diterbitkan tahun 1998).

(1997). Leading cange. (Terjemahan Joseph Bambang MS). New York: Harvard Bussines School Press. (Buku asli diterbitkan tahun 1996).

Kotter, J. P., \& Jamews, L. H. (1992). Corporate culture dan performance. New York: The Pree Press.

Moeslichatoen (2004). Metode Pembelajaran Taman Kanakkanak, Jakarta: Rineka Cipta

Noorlaila, Iva. (2010). Panduan Lengkap Mengajar Pendidikan Anak Usia Dini. Yogyakarta: Pinus Book Publisher

Palmer, J. A. (2003). Fifty modern thinkers on education. (Terjemah Farid Assifa). New York. (Buku asli diterbitkan 2001).

Parkay, F. W., Stanford, B. H., dan Jovita, R. G. (2008). Becoming a teacher. (Terjemah dari Dani Dharyani). Boston. (Buku aslinya, 2008).

Preedy, M. (1993). Managing the effective school. London: Paul Chapmen Publishing Ltd.

Ratna Wilis Dahar. (1988). Teori-teori belajar. Proyek Pengembangan Lembaga Pendidikan Tenaga Kependidikan: Jakarta.

Saphier, J., \& King, M. (1985). School culture. Good seeds grow in strong cultures, 114,115,120.

Savage, T. V., \& Armstrong, D. G. (1996). Effective teaching in elementary social studies. Amerika: Merrill an Imprint of Prentie Hall. 


\begin{tabular}{|l|l|r|}
\hline A1 Fitrah & $\begin{array}{r}\text { Pengembangan Nilai-nilai Kultur Positif } \\
\text { Journal Of Early Childhood Islamic Education } \\
\text { ISSN }: \text { 2599-2287 }\end{array}$ \\
Vol.1 No.2 Januari 2018 & Pendidikan Anak Usia Dini Berbasis Islam \\
\hline
\end{tabular}

Spradley, J. P. (1979). The ethnographic interview. New York: Rinehart and Winston, Inc.

Spradley, J. P. (1980). Paticipant observation. New York: Holt, Renehart and Winston.

Sujiono, Yuliani Nurani. (2009). Konsep Dasar Pendidikan Anak Usia Dini` Jakarta: Kencana Media Group

Tim Peneliti PPs UNY. (2012). Pedoman pengembangan kultur sekolah. Direktorat Pendidikan Menengah Umum, Depdiknas. Jakarta.

Wien Sukarsih. (2006). Manajemen berbasis sekolah SMAN 17 plus Palembang.

Young Pai. (1990). Culture foundations of education. London: University of Missaori at Kansas City.

Yus, Anita (2011). Model Pendidikan Anak Usia Dini. Jakarta: Kencana Media Group.

Zamroni. (2012). Mengembangkan kultur sekolah menuju pendidikan yang bermutu. Makalah disajikan dalam Seminar Nasional Peningkatan Mutu Pendidikan Melalui Pengembangan Budaya Sekolah, di Universiatas Negeri Yogyakara. 